Journal of Jazz Studies vol. 10, no. 2, pp. 119-156 (Winter 2014-2015)

\title{
Of Icons and Iconography: Seeing Jimmie Blanton
}

\author{
Matthias Heyman
}

\section{FROM ICON TO ICONOGRAPHY ${ }^{1}$}

Photographs and films of jazz musicians are an integral and important part of the music's history. On the one hand they document jazz and its musicians within a specific time frame, on the other hand they play "a central role in constructing an aesthetic for jazz, helping to frame the way the music is perceived and understood," as Tony Whyton writes in Jazz Icons: Heroes, Myths and the Jazz Tradition $(2010,6)$. In both cases visual representations of jazz musicians are one of the means used in constructing the jazz tradition (to borrow the title from Scott DeVeaux's seminal essay) and the icons that go along with that tradition. Although the public, and indeed many performers as well, are fond of iconized or romanticized representations of their favorite artists, they do not provide us with a truthful and holistic insight into these musicians' lives or music. Hence, jazz scholars often take it upon themselves to demythologize such icons, and in doing so use a variety of methods, ranging from literature review to archival research, transcription to music analysis. But there might be yet another way to help to demystify jazz icons besides these well-tested research methods.

Utilizing two case studies of bassist Jimmie Blanton I will show that in certain instances music iconography can be a valuable addition to the aforementioned methods, and is currently underused in jazz studies. ${ }^{2}$ Using

\footnotetext{
${ }^{1}$ This article is based on a poster titled Picturing Blanton: Visual Sources in Researching Jimmie Blanton's Bass Playing, presented at the Rhythm Changes II: Rethinking Jazz Cultures Conference in Salford, Media City UK, from 11 to 14 April 2013. This research is funded by a grant from the Research Programme of the Research Foundation - Flanders (FWO). The author would like to thank Anthony Barnett, Mark Cantor, David Chevan, Bill Crow, Richard Davis, Alexander Dhoest, Andrew Justice (the University of North Texas Music Library), Steven Lasker, Lewis Porter, Fred Reif, Ken Steiner, and the journal's editors for their help and suggestions.

${ }^{2}$ There are several pictorial anthologies focusing on jazz, such as The Jazz Image: Masters of Jazz Photography (Tanner 2006), but they seldom go beyond the coffee table format, and are hardly used as an analytical or interpretative tool. In his article "Black American Music in
} 
such sources might seem paradoxical given their use as a visual rhetoric to the construction of jazz icons, but as I will argue below, they can be effective tools in understanding and contextualizing the lives and music of jazz performers. In the first case study, I contextualize a statement jazz historian Gunther Schuller made in regard to Blanton's right hand posture, and show how music iconography provides useful information on such visually centered aspects like postures and performance stances. In less obvious cases such as analysis of tone and timbre, visual sources might also hold clues to further understanding. In the second case study, I focus on a non-visual element, Blanton's tone, and use photographic evidence to explore the production of the bassist's much praised sound. I conclude by taking iconography out of its more theoretical context and briefly look at how it might enhance performance practice within jazz. By looking at visual sources from these various perspectives, I suggest music iconography to be a useful tool to consider for everyone's arsenal, from jazz scholar to artistic performer.

\section{BLANTON THE REVOLUTIONARY!}

"The story of jazz revolves most often around the legacy of iconic figures, with a canon of masterpieces supported by a pantheon of jazz greats," states Whyton, neatly summarizing one of the dominant narratives in jazz historiography $(2010,16)$. He explains that these jazz icons serve a number of purposes, for example "to support the authority of the jazz canon, a sense of homogenous tradition and the romantic jazz life" $(2010,8)$. In his own exploration of this narrative, George Lipsitz describes how such jazz greats are often perceived as "heroic creative artist[s]," demonstrating how trumpeter Louis Armstrong is usually framed as "the prototypical genius who played better [...] than anyone else and whose creative innovations influenced everyone else," as for instance happens in the highly debated Jazz: A Film by Ken Burns from 2000 (2004, 11)..$^{3}$

Pictures: Some Themes and Opportunities" Frederick Crane acknowledges the validity of visual sources in this perspective, stating that "[t]he assembly and study of pictorial sources for the history of the music of black Americans offer limitless opportunities. Hardly anything has been done in the area of interpretation of historical pictures of any category of American music. The pursuit should be richly rewarding" $(1986,45)$.

${ }^{3}$ Writing on the canonical framing of jazz history, along with its icons and myths, is abound. Some essential reading is Scott DeVeaux's "Constructing the Jazz Tradition: Jazz Historiography" (1991) and Krin Gabbard's "Introduction: The Jazz Canon and its Consequences" (1995), as well as the cited works of Whyton (2010) and Lipsitz (2004), among others. 
In this jazz version of the "great man" theory, a select group of musicians is held responsible for specific stylistic achievements, or technical and instrumental advancements. Hence, the focus lies mostly on artistic individuals and their creations, but such narrow perspective fails to see these individuals and their work as part of a continuum in the complex patchwork that jazz history really is. However, over the last twenty years many jazz scholars have made considerable efforts to demythologize the music and lives of several of its icons, as Lewis Porter did in his study John Coltrane: His Life and Music (1998), while others have given lesser-known figures the acknowledgement they were due, as Walter van de Leur did in Something to Live for: The Music of Billy Strayhorn (2002). Yet to this day many jazz musicians are still treated as icons (which is hardly surprising given the fact Ken Burn's Jazz is still used in many jazz appreciation classes), whereas others continue to be seen as minor and thus less important performers. In both cases the subtleties of their "real" lives and true musical impact remain elusive.

Take for instance double bass player James "Jimmie" Blanton (1918-1942), best known for his tenure with The Duke Ellington Orchestra between 1939 and $1941 .{ }^{4}$ Many historians, musicians and critics consider Blanton to be one of the most important and influential bassists in jazz history, and he is widely credited for "revolutionizing" jazz bass playing (a trope I will explore below). But how did this notion of Blanton as "revolutionary genius" come into being? How did the bassist became a (minor) jazz icon, and how did this affect the way he was (and continues to be) perceived?

Already early on in his all-too-brief career Blanton was noticed by the jazz press. ${ }^{5}$ Down Beat introduces the then twenty-one-year-old bassist to its readership by stating that he "is attracting wide attention with his solid musicianship," also quoting Ellington who praises the newest addition to his band as the "best bass man in musicianship" ("Duke's New Bass..." 1939, 13). Non-trade journals were also quick to pay attention to Blanton. The Indianapolis Recorder, for example, described his bass playing as "really unique and fascinating and spine-chilling" (Ye Scribe 1939a, 12). Both newspapers

\footnotetext{
${ }^{4}$ Blanton's official first name was James, but he usually went by "Jimmie." Blanton always signed his autographs "Jimmie," but most writers spell his first name as "Jimmy," including Ellington in Music is My Mistress $(1973,164)$. In this article I will use Blanton's own preferred spelling, but when citing will leave the author's original spelling unchanged.

${ }^{5}$ Although Blanton played professionally in and around St. Louis earlier (with Fate Marable and the Jeter-Pillars Orchestra, among others), he entered the national limelight upon joining the Ellington band on November 3, 1939. Two years later, in mid-November 1941, he was forced to retire for health reasons, passing away from tuberculosis on July $30^{\text {th }}, 1942$. I would like to thank Ken Steiner for giving me access to the Blanton family archive.
} 
and trade journals continued to laud Blanton throughout his career, calling him (and his playing) "impressive" (Wright 1940, 18), "sensational" (Clark 1940, 19), "miraculous" (Barrelhouse Dan 1940b, 14), "virtuoso" ("Ben Webster Joins Ellington" 1940, 6), "exceptional” (Kolodin 1941a, 22), "peerless" (Freeman 1941, 5), and "creative" (ibid.). ${ }^{6}$ The young bassist was also acknowledged by fellow musicians, not only by the "Ellingtonians" (alto saxophonist Johnny Hodges expressed his admiration by stating that Blanton "plays more changes than any horn tooter," Ye Scribe 1939b, 12), but also by his fellow bassists, including John Simmons (1941), Milt Hinton (1941), Artie Shapiro (1941), John Kirby (1942), and Sid Weiss (Feather 1942) all singling out the newcomer as a favorite. ${ }^{7}$

It would, however, be wrong to conclude from the above that, during his lifetime, Blanton was already seen as the uncontested number one among jazz bassists. For instance, Blanton never finished first in the Down Beat and Metronome polls-the former voted by critics, the latter by its readership. In 1940 and 1941 Bob Haggart and Artie Bernstein finished first and second respectively in both magazines, with Blanton coming in third. One could simply brush this away as yet another example of the music industry's embedded institutional racism (Haggart and Bernstein were white and played in leading white bands, those of Bob Crosby and Benny Goodman respectively), but the reality was far more nuanced. Also bassists, white and black, listed other peers besides Blanton as their favorites, and the press devoted space to many other bass men as well, regardless of their race, praising for example Israel Crosby ("tremendous," Wright 1941, 32), Eddie Safranski ("impressive," Simon 1942a, 22), Gene Ramey (“unbelievable," ibid.), John Simmons ("talented," Toll 1941, 2), as well as publishing dedicated articles on Al Morgan (Freedman 1940), Jim "Slim” Taft (“Slim' Taft, Dorsey Bros.

\footnotetext{
${ }^{6}$ It seems that only the Ellington-Blanton duet sides of October 1, 1940, and most specifically the bowed sections, did not find approval with several critics, with for instance Irving Kolodin (for The New York Sun) calling them "fairly excruciating" (1941b, 29). Down Beat's Dave Dexter, Jr. held an even harsher opinion, and labeled them "the most sickening, unmusical, and thoroughly disgusting sides the Duke has ever needled. ["Body and Soul"] is hacked, slashed, and brutally butchered by Blanton's bullish bowing” (1941a). Dexter's review triggered a small debate among readers, with one Edward Gottlieb forcefully defending Blanton and questioning Dexter's critical judgment without actually knowing how to play the double bass (1941), and one Charles C. Sords in turn defending Dexter's stance (1941). Eventually Dexter, himself an amateur alto saxophonist, rebutted the critique by starting to "tak[e] string bass lessons from both Sid Weiss [...] and Artie Bernstein" (1941b, 4).

${ }^{7}$ All comments (save Weiss') come from Music and Rhythm, a short-lived magazine (November 1940 - December 1942) that regularly featured the musicians themselves as they picked their ten favorite colleagues or gave advice to budding instrumentalists.
} 
Bassist, Dies on Coast" 1941), Artie Bernstein ("Brother and Sister Gave Benny Bernstein" 1939; "Artie Bernstein Back to Coast Studios Forsaking the Hot and Harrowed" 1941) and Artie Shapiro ("Metronome's Hall of Fame: Artie Shapiro" 1941). ${ }^{8}$ Although Blanton was clearly considered one of the best bassists in the business, it seems that his canonization really started to take place after his passing. Indeed, as Whyton notes, "[o]nce deceased, jazz greats can be transformed into icons" $(2010,10)$. In obituaries and eulogies published shortly after the bassist's untimely death (on July $30^{\text {th }}, 1942$ ), we see the first signs of Blanton being elevated into the pantheon of jazz icons. Metronome's breaking of the news of his passing is worth citing at length:

Jimmy Blanton was a thrill in the lives of musicians to whom almost every possible thrill had come. Jazz veterans, the Ellingtonians were continually astonished by the musicianship, the inspiration and the technical agility of young Blanton. They spoke of little else when asked of news of the band. They volunteered raves about his playing at any and all times when they could find listeners. At 24 [he was still 23 upon passing, but was to become 24 on October 5, 1942], Jimmy Blanton represented the pinnacle of achievement on his instrument to just about all who heard him, in person or on records. His loss [...] is enormous. ("Duke's Blanton Dead at 24" 1942, 11)

Down Beat's report is more pragmatic, describing Blanton's final days and pointing out the "occupational hazard of the dance business," which writer Charlie Emge presumes to have led to the bassist's illness and ultimately to his demise $(1942,12)$. But the same issue carries an emotional eulogy, a poetic (and no doubt imaginary) rendering of the Ellington band's reaction upon hearing the news of their former sideman's death:

A tenor saxophone wailed disconsolately [...]; a piano wandered reminiscently ... almost broke [...]; a trombone cried. [...] And over the band ... over everything, rang the clear, vibrant, powerful, feeling tones of a sixteenth man, a man who wasn't there. [...] No, Jimmy wasn't there, but his bass rang out louder than any other instrument of Ellingtonia. He heard it all. Throwing of the yoke of an ill, troublesome body, he had returned to the band he loved. Jimmy is dead (dix 1942, 6).

This romantic mode of writing (or emplotment, to use historian Hayden White's term. 1973, 7-11), with a disembodied Blanton ("wasn't there") who

\footnotetext{
${ }^{8}$ Besides Blanton, the three most cited names by the aforementioned bassists in Music and Rhythm are Bob Haggart, Artie Bernstein, and John Kirby, neatly following most of the poll's rankings.
} 
just transcended the tragic circumstances of his everyday life ("throwing of the yoke...") and in death became one with his instrument and his music ("his bass rang..."), is a clear example of the bassist being cast as an otherworldly, yet omnipresent icon ("he heard it all"). However, this is the only known example that presents him as a spiritual icon (of which John Coltrane is the best example), and this romantic emplotment is not commonly used in consequent framings of Blanton-as-icon.

Over time a specific narrative around the figure of Blanton developed which posited him more than any other bassist as the prime performer of his instrument (which in turn made many of his first-rate contemporaries disappear from the public radar). In August 1946, Metronome published a feature-length article by Dave Koonce entitled "Late Jimmy Blanton's Bassdom Greatest," which introduced several intertwined tropes that constitute this narrative, and that eventually became embedded in virtually all writings on the bassist, not only in journalistic articles, but also in (college text) books and academic studies. ${ }^{9}$ The first trope posits Blanton as a "first": he was the first to bring "the string bass in the dance orchestra [...] out of relative obscurity;" he was "one of the first rhythm men to realize the difference between the chopped beat and the flowing beat;" he was "the first bass man to stray away from the basic one-three-five chords;" and he is described as the first to "have given arrangers new ideas on writing for the cumbersome and difficult instrument" (Koonce 1946, 48-49). In the second trope, Blanton is associated with modernism, sometimes literally ("Regardless of how modern his playing was, it was always pretty"), sometimes less overt ("[he] was the first bass man [...] to begin experimenting with flatted ninths, flatted fifths and thirteenths") (ibid., 49). Not only is he posited as the first modern bassist, the article also presents him as the inspiration of a "new school of bass playing [from which] came Oscar Pettiford, Trigger Alpert, Chubby Jackson, and many others not as well known," emphasizing that "his influence on modern bass playing will be felt for years," and that "[b]ass men can thank him for what he has done to bring out the importance of the string bass," all elements that transform Blanton from one of the leading bassists of his generation into the leading bassist, who in turn inspired the next generation(s) of bass men (ibid.). ${ }^{10}$ All these tropes-

\footnotetext{
${ }^{9}$ Another early tribute to Blanton, "First Bassman-Jimmy Blanton," appeared in Band Leaders, March 1945 (Garrison 1945, 60). Although the title refers to the "first" trope, the article itself does not explore this nor any of the other tropes that later appeared in the Metronome feature. ${ }^{10}$ Indeed, Pettiford, Alpert and Jackson did express their admiration for Blanton at one point or another, though sometimes only years after the publication of this article. Alpert is not a familiar name anymore, but at the time he was best known for his earlier tenure with Glenn Miller's civilian and Army Air Force band.
} 
Blanton as the first, modern, and leading bassist-are closely related and are in several cases used interchangeably, but combined they produce the most dominant trope in the bassist's canonized narrative, and one that is not spelled out literally in this article: that of Blanton as a "revolutionary" bass player. ${ }^{11}$ This specific term seems to have been used for the first time in an article by Barry Ulanov from Jazz 1950: The Metronome Yearbook. In a discussion on "the four men who made modern jazz"-that, besides Blanton, cites tenor saxophonist Lester Young, trumpeter Roy Eldridge, and guitarist Charlie Christian-(1950,19), Ulanov explains that the bassist "went much of the way toward revolutionizing the rhythm patterns which, unchanging, gave every indication of constricting and eventually killing jazz" (1950, 21). Besides positing Blanton as a transitional figure between Swing and Bebop (or modern jazz, as Ulanov calls it), he also reiterates the aforementioned tropes, for instance by presenting him as the first "[to bring] his instrument to maturity, [and to give] it a solo position in jazz $(1950,21) .^{12}$

The "revolutionary" trope quickly became a fixed part in writings on Blanton: the concert program of Norman Granz's "Modern Jazz Concert" tour, which besides the Ellington band included Gerry Mulligan, Dave Brubeck and Stan Getz, states that "he revolutionized the art of the jazz bass" (1954); in a Down Beat feature, bassist Wendell Marshall, Blanton's first cousin and himself an Ellingtonian from 1948 to 1955, explained that "[i]t was Jimmy [...] who really revolutionized jazz bass" (Hentoff 1955, 6); and Leonard Feather's The Book of Jazz has Blanton down as the "musician who revolutionized the concept of the instrument's capabilities" $(1959,120) .{ }^{13}$ The list goes on: a Jazz Journal article by Barry McRae (1967, 15); Ellington's Music is My Mistress (1973, 164); the liner notes to ABC Impulse's The Bass, written by Robert Palmer (1974); Blanton's entry by Ray Brown in the New Grove Dictionary of Music and Musicians (1980, 2:784); John Edward Hasse's Beyond Category: The Life and Genius of Duke Ellington (1993, 234); The History of Jazz by Ted Gioia (1997, 185); Jazz by Scott DeVeaux and Gary Giddins (2009, 288); Henry Martin and Keith Waters' Essential Jazz: The First 100 Years, $3^{\text {rd }}$ Edition (2014, 104)- they all present Blanton as a revolutionary bassist, or use slight variations

\footnotetext{
${ }^{11}$ Also note that revolutionaries are often seen as heroes by their following (think George Washington or Che Guevara). Hence Blanton's "revolutionary" trope equates him to a "heroic creative artist" (Lipsitz 2004, 11).

${ }^{12}$ Ulanov's discussion of these "four men" later appeared in an expanded form (with large sections quoted verbatim, including the above) in the chapter "Figures of Transition" in $A$ History of Jazz in America (1952, 235-46).

${ }^{13}$ Moreover, the lead-in of the 1955 Down Beat article refers to Blanton as "legendary," another clear marker that identifies him as a jazz icon $(1955,6)$.
} 
on this trope, for instance by positing him as a pioneer, an innovator, a prodigy, or a genius. ${ }^{14}$ Even some academic works use these clichés without questioning them or reflecting upon their iconic framing and meaning, as the title of William Law's unpublished master's thesis "Establishing Jimmy Blanton as The Father of Modern Jazz Bass Through Examination of Selected Works" makes clear (1994). ${ }^{15}$

It is not my goal here to prove or disprove that Blanton was a revolutionary bassist-that is in part done in the aforementioned studies-but the fact remains that these manners of representation, which have permeated writings on the bassist for at least sixty-eight years, clearly establish him as an artistic hero in the pantheon of jazz (bass) history. Such sweeping statements are problematic in at least two ways. Firstly, they do not situate Blanton's work in relation to that of his precursors and contemporaries, thus failing to provide a full picture of jazz bass development in this era. Jazz bass historian David Chevan observed as early as 1989 that "so many jazz historians have emphasized the preeminence of Jimmy Blanton to the neglect of other bassists" (1989, 73). Indeed, some of the better known bassists such as Walter Page (1900-1957) or Milt Hinton (1910-2000) will often be mentioned in passing, but are given considerably less attention than Blanton, downplaying their contributions to the development of jazz bass playing. ${ }^{16}$ This observation is echoed in this comment by bass scholar John Goldsby: "We tend to credit innovators but not developers. Those who break new musical ground are often held up as heroes [...] but often at the expense of the thousands of players who take new techniques and refine them" (2002, xii). Secondly, iconic writing

${ }^{14}$ I deliberately sampled from a wide variety of sources (i.e., articles, liner notes, (auto)biographies, history books, college text books, and dictionary entries), authors (i.e., writers, critics, academics, and musicians), and from every decade to illustrate how this trope permeates virtually all jazz writing.

${ }^{15}$ There is a surprising number of studies of Blanton's bass playing, in itself an indication of his stature. To my knowledge there are at least three master's theses and three doctoral dissertations that focus at least partially on Blanton, not including my own ongoing doctoral research. Some of these academic works question or at least give nuance to Blanton's iconic status to a certain extent, but as all of them are unpublished, they are rarely consulted by writers or critics.

${ }^{16}$ It is even more remarkable that several bassists who in the early 1940s were held in high esteem by critics, fellow musicians and the public are all but forgotten today. Some might be remembered for other associations, like Bob Haggart as the composer of "What's New," whereas others like Jack Ryan ( $8^{\text {th }}$ place in Down Beat's 1939 poll) are often not even vaguely familiar to today's jazz bass experts. Also note that no dissertations or theses have been written on any of the pre-Blanton bassists, and to date no bassist garners as much academic attention (see previous footnote). 
takes Blanton's bass playing at face value and reduces his apparent innovations to a superficial list of stereotypical styles and techniques. Consider for instance this excerpt from Blanton's entry by J. Bradford Robinson in The New Grove Dictionary of American Music and Musicians (1986, 2:232), which later appeared virtually unchanged in both editions of The New Grove Dictionary of Jazz (1988, $1: 117$; 2002, 1:238) as well as in the digital collection Grove Music Online (2001):

In his tragically brief career, Blanton revolutionized jazz bass playing, and until the advent of the free-jazz styles of Scott LaFaro and Charlie Haden in the 1960s all modern bass players drew on his innovations. He possessed great dexterity and range, roundness of tone, accurate intonation, and above all an unprecedented swing. His strong sense of harmony led him to incorporate many nonharmonic passing tones in his accompaniment lines, giving them a contrapuntal flavor and stimulating soloists to their own harmonic explorations. Blanton also contributed the earliest fully satisfying jazz solos on this instrument, which depart in their inventive melody and flexible rhythms from the "walking" bass style that was then prevalent.

Besides reinscribing the "revolutionary" and "first, modern and leading bassist" trope, Robinson lists the many innovations one finds usually associated with Blanton. However, none of these are analyzed, contextualized, or backed up with notated music or references to exemplary audio samples that might illuminate what these innovations actually entail. ${ }^{17}$ Also the sources that support this entry merely sum up Blanton's pioneering aspects without any indepth exploration. ${ }^{18}$ Hence, the question remains on what Robinson based his

${ }^{17}$ That a dictionary entry can be approached quite differently is demonstrated by Manfred Straka's entry on Blanton in the German Die Musik in Geschichte und Gegenwart: Allgemeine Enzyklopädie der Musik (2000, 3:50-51), which includes written analysis, excerpts from transcriptions, and discographical references to exemplary tunes to support his claims.

${ }^{18}$ Not only are all sources for the original entry outdated, they also stem from journalistic literature. In 2002 Gunther Schuller's The Swing Era: The Development of Jazz, 1930-1945 (1989) was added, but since Robinson's entry was not fundamentally revised since its inclusion in the so-called "Amerigrove" from 1986, it is unclear what this academic source contributed, and why it was included in the first place. The fact remains that the entry is largely based on non-academic literature in which the more technical aspects of music are not researched in depth, and thus are taken for granted. Chevan observes that "problems arise when scholars turn to these secondary sources for their information," citing Robinson's entry as an example of this common practice $(1989,75)$. Also bassist Rex Bozarth points to this problem: "Most writers $[\ldots]$ have relied on hearsay information, existing oversimplified reports, and a limited number of the available records" $(1981,2)$. Although this assessment was written in 1981, it 
insights. This is typical of most writings on Blanton, and indeed of many other jazz greats as well, who because of their iconic stature often defy or escape critical analysis. ${ }^{19}$ To be clear, I do not mean to suggest that Blanton does not deserve to be called a revolutionary, pioneering or innovative bassist, but this iconic framing often leads to oversimplifying notions that do little justice to his (and his peers') bass playing.

\section{HEARING BLANTON}

A notable exception where some of Blanton's bass playing is analyzed is Schuller's seminal study The Swing Era (1989) ${ }^{20}$ Surprisingly, Schuller chooses to focus almost entirely on an aspect that often eludes formal analysis: tone. ${ }^{21}$ Although tone, and the closely related term "timbre" are considered to be key parameters in jazz, they are mostly described in rather vague, even poetic terms. ${ }^{22}$ Consider for instance these typical descriptions of Coleman Hawkins and Lester Young, two Swing era tenor saxophonists who are often seen as diametrically opposed to each other in virtually every aspect, including tone, with Hawkins having an "aggressive robust style" and a "hard-tongued approach" (Schuller 1989, 548), whereas Young's playing is described as "pellucid," "mauve-toned" (ibid., 552) and "weightless" (ibid., 556). As Barry Kernfeld writes, this kind of "vague analogy" is "the only alternative to mathematical analysis" $(1995,168) .{ }^{23}$ Besides its haziness, describing musicians as such leads to stereotypical thinking and writing, as in the above example of

remains valid as far as Blanton is concerned (some exceptions such as Straka 2000 notwithstanding).

${ }^{19}$ See for instance the introduction to van de Leur's Something to Live for: The Music of Billy Strayhorn (2002, xv-xxiii), in which he sketches how Ellington's iconic status led many writers to downplay or even neglect Strayhorn's contributions to the Ellington band.

${ }^{20}$ As noted in footnote 15 , there are also several academic works that include in-depth analyses of aspects of Blanton's playing.

${ }^{21}$ Brian Priestley writes that "instrumental tone is still one of the aspects of jazz performance thought as god-given and somehow unaffected by any conscious learning process" $(2011,205)$. This might be one of the reasons why tone is given so little attention in analyses of instrumental styles.

${ }^{22}$ Although some distinguish between tone and timbre, the difference is very subtle. In The New Grove Dictionary of Music and Musicians, $2^{\text {nd }}$ edition, tone is described as "the quality of a musical sound" (Drabkin 2001, 25:599), whereas timbre is specified as "a term describing the tonal quality of a sound" (Campbell 2001, 25:478). Hence, most writers use both terms interchangeably.

${ }^{23}$ By "mathematical analysis," Kernfeld means the "representations of the frequency spectrum of instants of sounds," which he acknowledges not to be "particular helpful for critical description" $(1995,168)$. 
Hawkins as the ultimate "hot," masculine representation of the jazz musician, and Young displaying the more "cool," feminine side, a prime example of the oversimplified polarities that permeate the jazz narrative (Whyton 2010, 157). It goes without saying that such well-worn clichés do not help with the deconstruction of the jazz canon and its icons. Although these descriptions give the reader a sense of the tonal quality of a musician without actually having to listen to him or her, and as such might be useful metaphors, it would be commendable for such "impressions"-striking as they sometimes might beto be complemented with more concrete analyses or contextualizations to yield a more precise image of the musician under question, something Schuller does not always do. ${ }^{24}$

Blanton does not escape these kinds of stereotypical descriptions, as his tone is characterized as "astonishingly full" (Schuller 1989, 111), "outsized" (Hasse 1993, 234), "resonant" (Gioia 1997, 186), "roaring” (Kernfeld 1995, 214), and "huge" (Goldsby 2002, 49). As it happens, all of these characterizations point towards one specific aspect of tone: the dynamic intensity of sound, or volume. But although this might be more explicit than hazy depictions as for instance singer Billie Holiday's "olive-toned timbre" (Schuller 1989, 530), the reader is still left with many questions. Was Blanton's tone that different from other contemporary bassists, and if so, in what way? ${ }^{25}$ Was the sheer volume the only remarkable aspect of his tone? What exactly made the young bassist's tone so voluminous? ${ }^{26}$ And how did he actually produce it?

It is this last question that Schuller analyzes in detail, providing a clearly defined and quite technical answer that seems to take away at least some of the

\footnotetext{
${ }^{24}$ In the introduction of Jazz Among the Discourses, Krin Gabbard further discusses the problematic use of such journalistic terms (as opposed to "scholarly prose") in Schuller's writing (1995, 11-12). Earlier, in his review of The Swing Era, Lewis Porter already pointed out this and several other flaws in Schuller's work (1991, 183-200).

${ }^{25}$ Contemporary reports reveal that Blanton was far from the only bassist whose tone was singled out, with critics positively reviewing for instance George Duvivier ("big tone," Ulanov 1942, 26), Eddie Safranski ("wonderfully warm tone," Simon 1942a, 22) and Vernon Alley ("full, rich tone," Simon 1942b, 14). Also nearly every bassist featured in Music and Rhythm (see above) stressed the importance of a good tone, suggesting that this was an aspect of bassmanship held in high esteem by most Swing era bass players. As later writers and historians devoted most attention to Blanton, the impression was created that his tone was far more remarkable than that of his fellow bassists, which is not what reviews in 1940s trade journals imply.

26 "His bass" is an obvious answer to this question. Blanton might have possessed an instrument with remarkable sound qualities, and I will address this hypothesis further in this article.
} 
mystique surrounding Blanton's bass playing. But despite this apparent demystifying effort, he does continue to iconize Blanton, describing him as the only one able "to unlock the secret of how to make a bass string vibrate longer and with a fuller resonance," and comparing him to "an acoustic scientist" $(1989,111)$. Schuller credits the bassist for being "the first to develop the long tone in pizzicato" (ibid.)-again reiterating his iconic status-and lists four elements that made this development possible, the vital one being the posture of the right hand:

Blanton realized that $[\ldots]$ you could maximize the natural resonance of the string by using as much of the fleshy length of the finger as possibleplucking the string with the finger parallel to the string, rather than plucking straight across at right angles (ibid.).

This is in fact a description of the "anchored" right hand posture, with the thumb anchored on or behind the fingerboard, which enables the bassist to pull the strings sideways with the finger, usually the index finger, pointing downwards towards the bridge (as opposed to the "unanchored" posture, which is detailed below). This posture is believed to facilitate dexterity, allowing bassists "to adopt the improvisational vocabulary typically performed by instruments such as the saxophone, piano, or trumpet," and play virtuoso solos in a "horn-like" style (Campbell 2002, 23-24). The horn-like style eventually became the favored mode of solo expression of many bassists, and most of them consequently adopted the anchored right hand posture that was believed to be necessary to adequately perform this "modern" style of bass soloing. In fact, the anchored posture (or a variation of it) is to this day still preferred by a host of bassists, from budding students to the best-known names in the industry. ${ }^{27}$

With the above statement Schuller implies that Blanton was the first to use this particular posture, and since the bassist was indeed one of the earliest to play horn-like solos, this assumption seems logical. ${ }^{28}$ Bassist Jeffrey Campbell explains this in his doctoral dissertation "Two Profiles in the Development of Jazz Bass Playing: A Study of Jimmie Blanton and Ron Carter" (2002). He briefly discusses the development of the right hand posture, and concludes that Blanton was the first one to modify the "unanchored" right hand posture into an anchored, “'across the fingerboard' [quotation marks in

\footnotetext{
${ }^{27}$ It suffices to look at the wealth of film footage of performances by jazz bassists from the mid-1950s to this day to see the anchored right hand posture in action.

${ }^{28}$ See for instance Brian Priestley's comment in Mingus: A Critical Biography: "the startlingly melodic and horn-like work of Jimmy Blanton showed all the bassists the way of the future, and set the standard for many years to come" $(1982,16)$.
} 
original] pizzicato" $(2002,22)$, an innovative technique that allowed him to play the typical "eighth-note articulation" needed for horn-like solo playing $(2002,24)$. However, as I will make clear below, this issue is not so clear-cut, and more research is needed to confirm or disprove the notion that Blanton was indeed the first to use this modern right hand posture.

\section{SEEING BLANTON}

To gain further insight into this matter I turned to music iconography, an unlikely source given the prevalence of the sound recording as a basis for music analysis within jazz. Although iconography, or the use of visual sources, is not entirely new in the field of jazz studies, it has so far been used in completely different contexts, for instance to study record cover design or representations of jazz in American cinema. ${ }^{29}$ However, these uses do not take full advantage of what music iconography has to offer. As stated on the website of the Research Center for Music Iconography of the City University of New York, the United States' oldest and only such research center, music iconography can provide information on "instruments [..] and their structure, playing techniques, and use in ensembles; performers and composers" as well as "performance settings [...], including details of the acoustics in historical settings, or the makeup and placement of musical ensembles" (Research Center for Music Iconography 2014; http://rcmi.gc.cuny.edu). In this regard, almost every photograph and film excerpt of a performing jazz musician holds a wealth of useful information. Returning to Schuller's and Campbell's statements on Blanton as the pioneer of the anchored right hand posture, it would only seem logical to use images of the bassist's posture to back up this thesis, something that obviously has not been done as will become clear from what follows. Both authors are not to blame here, however, for a likely reason for not cross-referencing their writing with visual sources might be their scarcity in regard to Blanton. ${ }^{30}$

The Duke Ellington Orchestra recorded prolifically at the time of Blanton's engagement, as well as ceaselessly touring the country, but surprisingly few photographs of the band have survived to this day, whereas other images of the bassist are not readily available, or have simply not

\footnotetext{
${ }^{29}$ General information on iconographic studies in jazz can be found in Gabbard's essay "Images of Jazz" from The Cambridge Companion to Jazz (ed. Cooke and Horn 2002) and in the subchapter "Icon as Visual Image" from Whyton 2010.

${ }^{30}$ Campbell does include two photos to illustrate the unanchored posture, but neither of them are of Blanton (but of Slam Stewart and Eddie Safranski instead).
} 
(re)surfaced so far. Thus, all that remains is a handful of pictures of Blanton. Moreover, in this particular context posed photographs are not useful as a study object, since they do not always accurately depict playing stances. ${ }^{31}$ So what we need here are images that clearly show Blanton's right hand posture while he is playing. There are a few photographs that fit this description, and at first we see Schuller's thesis confirmed. In photograph (1), Blanton's index and middle finger of his right hand are clearly held parallel to the strings, indicating the anchored posture. On the following photograph (2) we can see a similar right hand posture, the main difference being that only the index finger is shown. However, Blanton did not exclusively use this posture, since in photograph (3) his right hand is held in a horizontal position and the bassist is clearly holding his fingers sideways, not downward as one would expect with an anchored posture. Moreover, photograph (4) illustrates Blanton's right hand "frozen" in mid-air action, and it is clear that his thumb is not anchored on or behind the fingerboard. Both pictures in fact illustrate the unanchored right hand posture, with the thumb positioned above the fingerboard instead of on or behind it and the bassist pulling outward with his plucking finger(s) held parallel to the fingerboard, not to the strings as with the anchored posture. As can be observed from photos and film footage of performing bassists in the 1930s and early 1940s, this unanchored posture was then prevalent, and can thus be considered the "traditional" right hand posture. ${ }^{32}$

A complete survey of the characteristics and development of the right hand posture in jazz bass playing is beyond the scope of this paper, but one thing has become clear: even though Blanton is often described as the first modern bassist in jazz, at least in terms of his right hand posture, he was much more of a transitional figure, using a combination of the traditional unanchored right hand posture, and the more modern anchored posture. ${ }^{33}$ (Please note that the terms "traditional" and "modern" are not used here as value judgments, but merely as a marker of distinction between a posture that

${ }^{31}$ I discuss the limitations of iconographic sources below.

${ }^{32}$ It must be noted that in most cases the sound was recorded separately from the visuals, so even when appearing to be performing live, musicians to some degree still "acted out" their part as the stage performer. Hence there is an element of show that must be taken into account, leading some bassists to exaggerate their movements to add to the visual attraction. Nonetheless, there are ample excerpts that accurately depict the movements of the performing musicians.

${ }^{33}$ Bassist Ray Brown briefly discusses the use of right hand playing techniques during a master class that was taped by the BBC in 1976. From a historical point of view this overview has its flaws, but it does provide a good insight into the use and sound of both the unanchored (4'08") and anchored (4'22") right hand posture. A clip can be found on: http://www.youtube.com/watch?v=SmoIvdWJpdQ. 
is no longer in use, and one that continues to be employed by today's bassists.) Of course one might rightly argue that four photographs do not make a convincing case, but pictures not included in this article show an almost equal use of both the anchored and unanchored right hand posture: of a total of thirteen relevant photographs (clearly showing Blanton's right hand in a nonposed, playing stance), five show the unanchored posture, four show the anchored posture, and four are inconclusive. When cross-referencing this with the existing film footage, which I do below, I believe this thesis is justified.

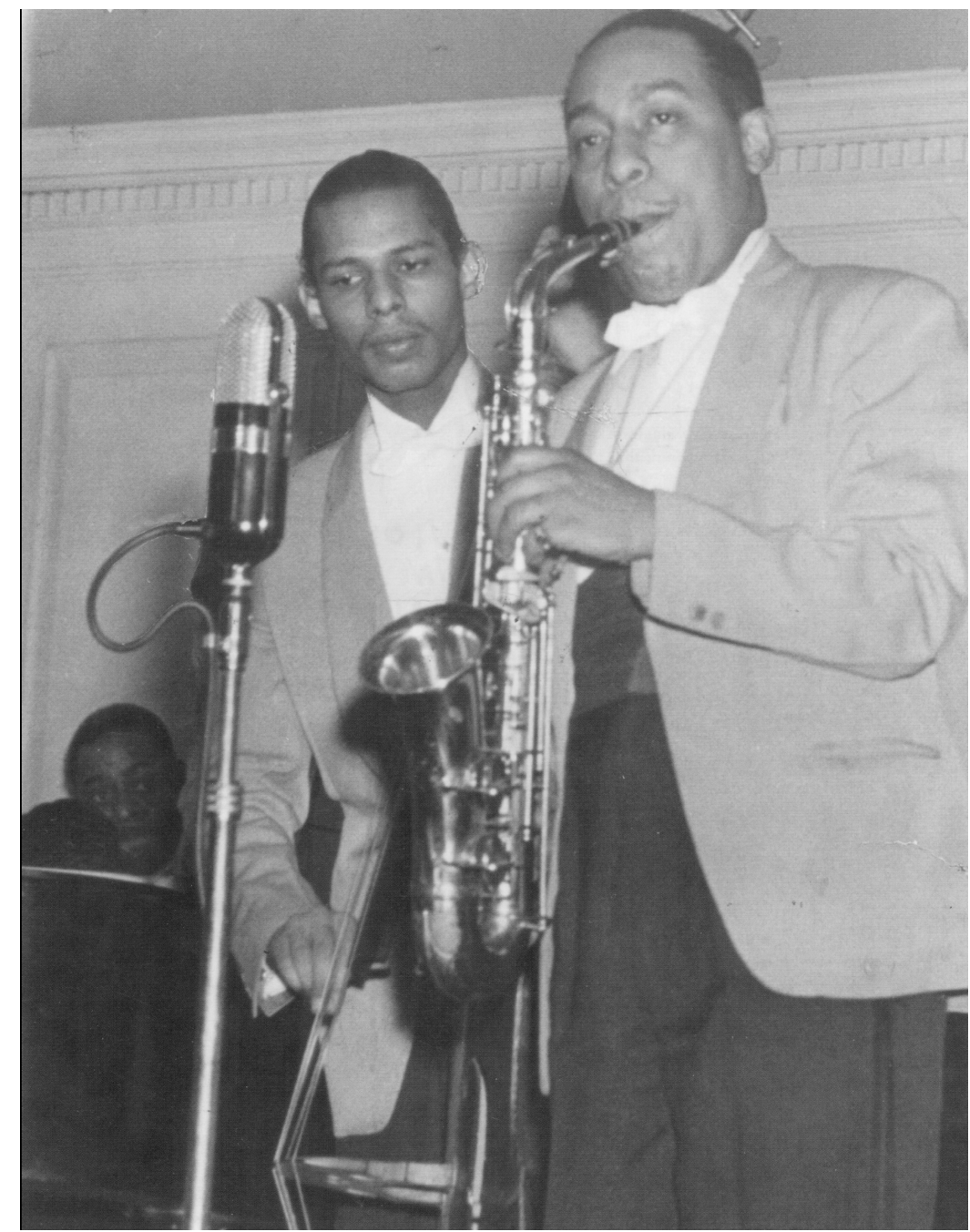

Photo 1: Blanton and alto saxophonist Johnny Hodges, Colgate University, Hamilton (NY), December 12, 1940 (photograph by Otto Hess, original [uncropped] appeared in Metronome, January 1941, p. 11. Every effort has been made to identify and acknowledge the rightful owner of this photograph). 


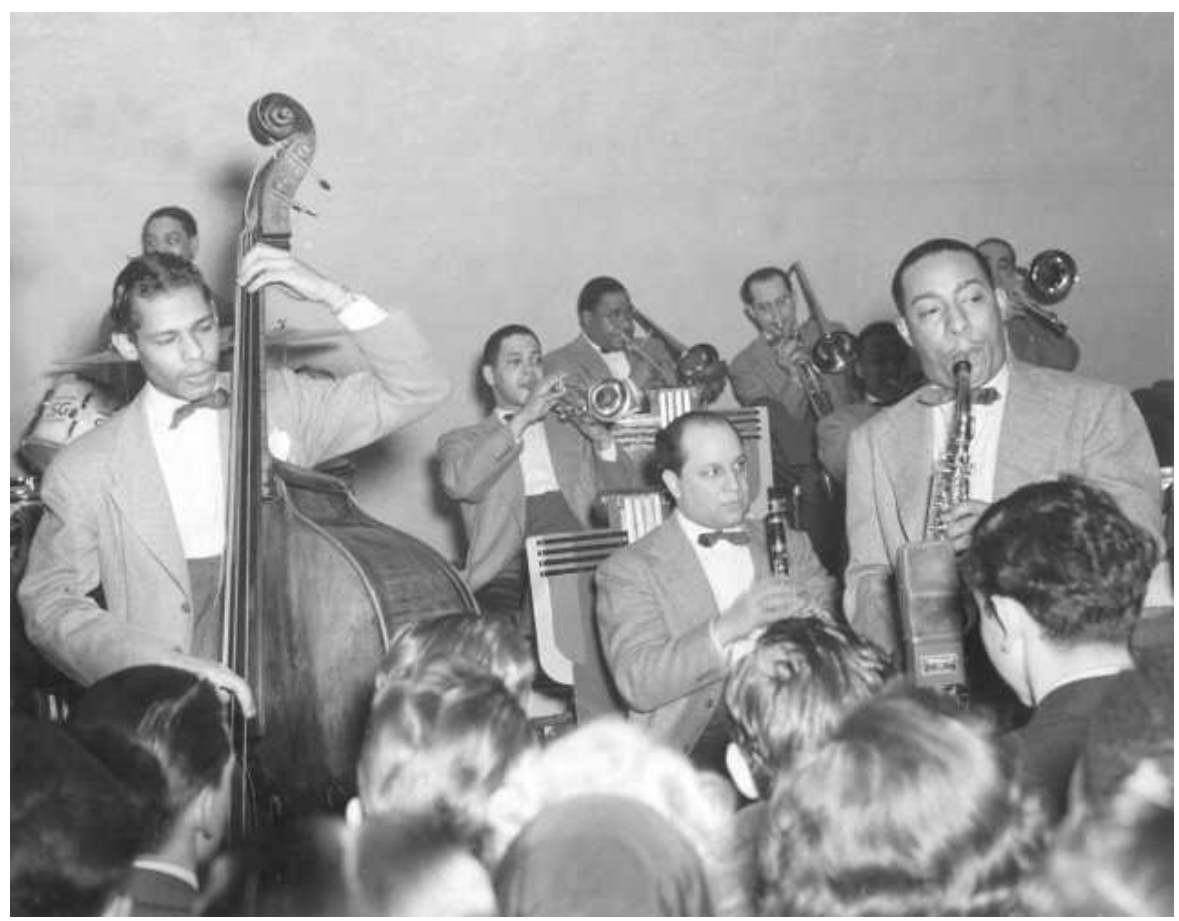

Photo 2: Blanton with clarinetist Barney Bigard (seated) and Hodges, Century Ballroom, Tacoma (WA), March 30 or 31, 1941 (Photograph by Red Kelly, Red Kelly Collection, Tacoma Public Library, RK-A15-04).

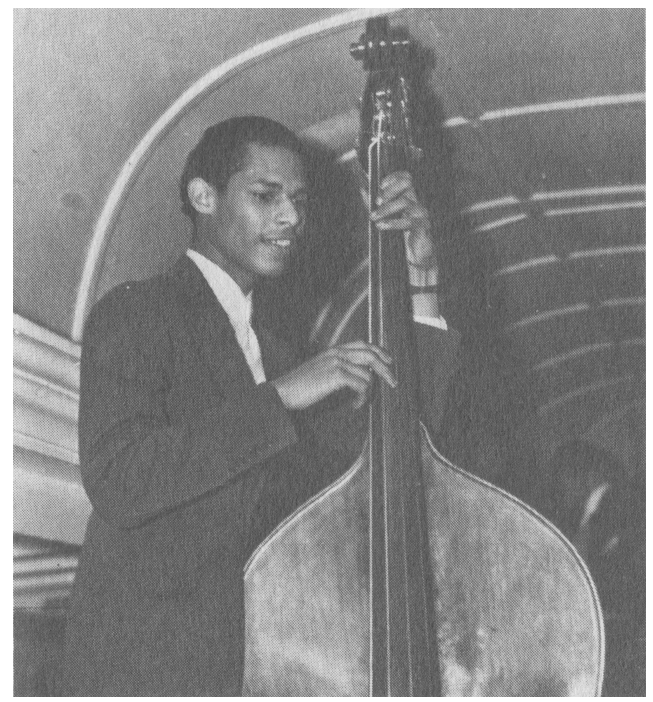

Photo 3: Blanton, possibly with Fate Marable's band, St. Louis (MO), summer or early fall 1939 (Photograph by Sinbad Condeluci, original [cropped] appeared in Down Beat, 15 December 1939, p. 13. Every effort has been made to identify and acknowledge the rightful owner of this photograph). 


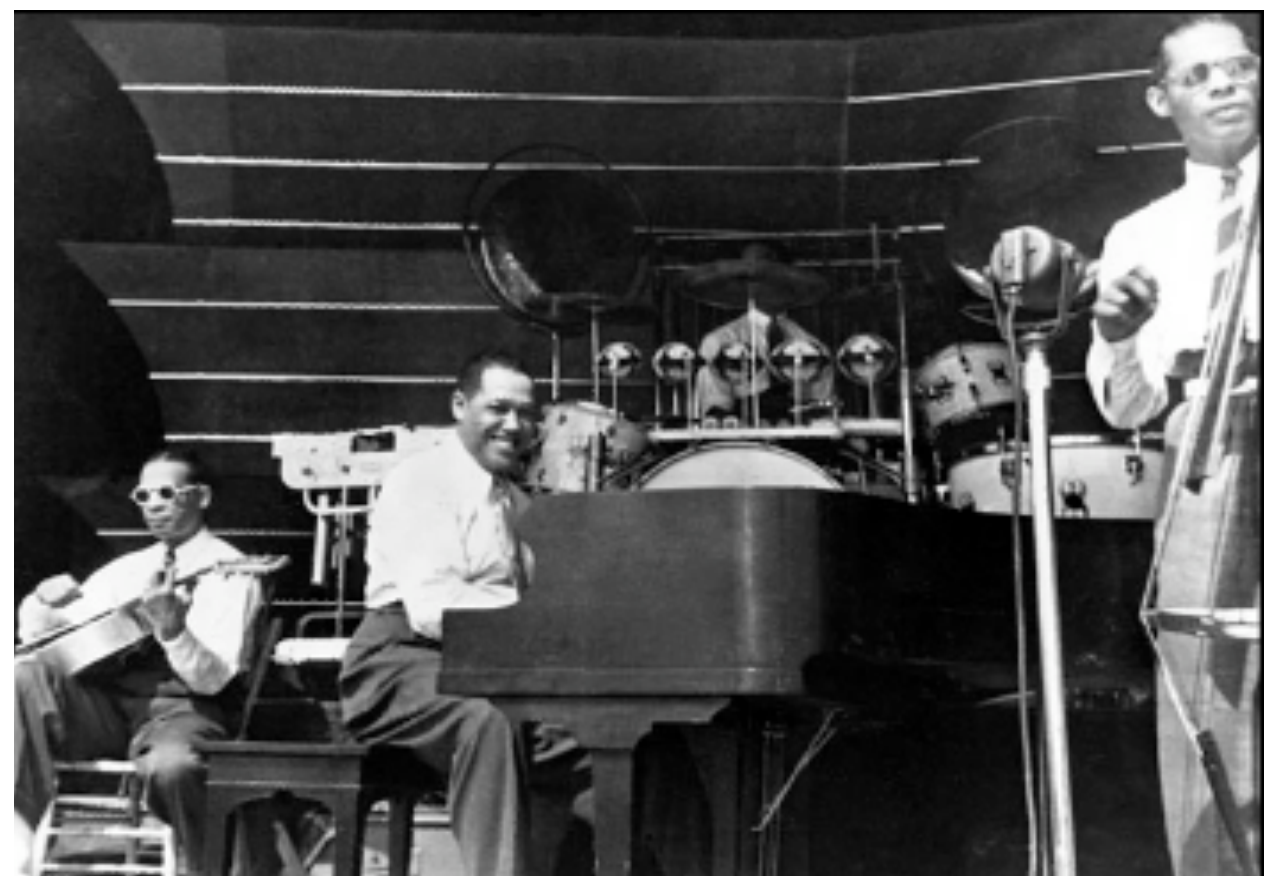

Photo 4: The Ellington rhythm section with Fred Guy, Duke Ellington, Sonny Greer (obscured) and Blanton, Eastwood Gardens, Detroit (MI), July 28, 1940 (Photographer unknown. Frank Driggs Collection, Archives Center, National Museum of American History, Smithsonian Institution).

As the above demonstrates, examining photographs can lead to a better understanding of certain technical, practical and stylistic elements pertaining to musicians. However, photos are also limited in the information they can provide and can sometimes lead to speculation, as with posed pictures or when, as in the case of Blanton, only a limited number of photographs are available. What would be even more informative are films, since they document the physical movement of the musician playing, and move beyond the static representation of a still photograph. As far as is known, there are only two film clips that include Blanton, both from private home movies unfortunately not readily available to the general audience. Between 1938 and 1941 baritone saxophonist Harry Carney filmed (silent $16 \mathrm{~mm}$ in color) his bandmates in the Ellington orchestra at informal moments, and Blanton can briefly be seen in conversation with one of his colleagues (possibly Barney Bigard) in a candid shot filmed during an outing to the Mt. Baker-Snoqualmie National Forest (which dates this outing to the first half of March 1941, when the band played 
several one-nighters in northern Washington State). ${ }^{34}$ For the purpose of this article these few seconds of Blanton have little value as the young bassist is not shown in the act of performing. The other footage, however, includes several revealing shots of the bass man in action. The entire film (silent $8 \mathrm{~mm}$ in blackand-white) lasts about eleven minutes (one fragment of seven minutes, and one of four), and was shot by Andy and Mary MacKay, two jazz aficionados from Los Angeles who filmed the Ellington band during the run of the musical revue Jump for Joy at the Mayan Theater in Los Angeles in the summer of 1941. ${ }^{35}$ Due to union regulations, the Ellington band was required to play Jump for Joy from the orchestra pit rather than on stage (only Ellington and trumpeter Rex Stewart were briefly on stage during the performance of Stewart's feature piece "Concerto for Clinkers"), but the MacKays also filmed the band during the jam sessions that brought the orchestra out of the pit to close the revue. Blanton is positioned in front of the band (albeit rather untypically on the right hand side, from the audience's perspective), and can clearly be seen in six separate fragments, ranging from four to eleven seconds, totaling an approximate thirty-five seconds. However, these few excerpts are more than revealing. Whereas still pictures showed a near-equilibrium between Blanton's unanchored (five photos) and anchored (four photos) posture, the film footage tells a different story. All excerpts, save one, show Blanton using the traditional (i.e., unanchored) approach, moving his lower left arm and hand outward after plucking the string. At one point one can even see him forcefully extending his entire arm, as if to (both aurally and visually) accentuate the note he is playing at that time. Only one five-second fragment depicts Blanton playing with his hand and arm completely stationary, implying the modern (i.e., anchored) right hand posture.

Why did he choose to use the anchored posture at this given moment? My personal experience as a jazz bassist leads me to two possible explanations: tempo and function. As this is silent footage, and it does not play back in real time ( $8 \mathrm{~mm}$ format has sixteen frames per second), we have no exact idea of the music's tempo in this fragment. However, it is possible that this was a faster or

\footnotetext{
${ }^{34}$ The Harry Carney Home Movies are part of the Ruth Ellington Collection, 1940-1991, which is in the holdings of the Archives Center at the Smithsonian Institution's National Museum of American History in Washington, D.C. This brief segment (alongside other segments of the Carney home movies) is reproduced in its entirety in Robert Levi's "Duke Ellington: Reminiscing in Tempo" for PBS's The American Experience series (1991).

${ }^{35}$ The MacKay footage is part of the private collection of jazz film archivist Mark Cantor (Celluloid Improvisations), and will be the centerpiece of a documentary he at the time of this writing is making on Ellington's Jump for Joy. I wish to thank Mark Cantor for allowing me to see this exclusive footage.
} 
up-tempo piece where a stationary, anchored hand allows for more stability and stamina. Unfortunately the excerpt does not reveal anything conclusive in this matter. What it also does not reveal is the bass's function: does Blanton only accompany in the footage, or is he perhaps seen soloing in these few seconds? This is a pertinent question, for we have seen before that an anchored posture is generally believed to be a necessity to play horn-like solo lines. So it might be possible that Blanton reserved the anchored posture for his solo outings, and the unanchored posture for his regular supportive work (walking bass lines, two-beat lines, etc.). No proof can be found in this short film, but circumstantial evidence suggests otherwise. In 1945, Oscar Pettiford (19221960), who is generally considered to be the next evolutionary step after Blanton, made a brief appearance in the motion picture The Crimson Canary alongside Coleman Hawkins and trumpeter Howard McGhee, among others. ${ }^{36}$ Some sources, such as David Meeker's Jazz on the Screen: A Jazz and Blues Filmography (2014, 331), suggest that the actual bass part was dubbed by an obscure bassist named Budd Hatch, but I am convinced that it is actually Pettiford himself who "sidelined" his own playing, something with which jazz film expert Mark Cantor concurs (e-mail message to author, June 21, 2013). Not only does this virtuoso and horn-like solo sound very much like Pettiford, it also is quite puzzling how an obscure bassist like Budd Hatch-assuming that it was him on the soundtrack-was able to play so masterfully and yet remain entirely unnoticed by the jazz community, then and now. Surely some excellent bassists have escaped the public radar, but this level of virtuosity would certainly have garnered some attention from fellow musicians. Hatch, however, was never a sideman for any real name band, recorded only a handful of albums, and his playing (often on tuba instead of double bass) can best be identified with the so-called Dixieland style, his main association being with trumpeter Pete Daily and His Chicagoans. The point is clear: he is hardly the bassist one would find playing the type of boppish bass solo heard on The Crimson Canary, and most definitely not as early as 1945 . With the same bassist on screen as well as on the soundtrack, we are confronted with a paradox: we see Pettiford use an unanchored posture, yet we hear him play a horn-like solo. ${ }^{37}$ So even though an anchored posture might facilitate playing such virtuoso lines, this clip proves that it certainly is not a necessity, a corollary sometimes made (e.g., Campbell 2002, 22-23). Thus, we cannot

\footnotetext{
${ }^{36}$ The relevant clip can be found as Hawkins riff tune - 1945 via: http://www.youtube.com/watch?v=UQh-tqrhn28.

${ }^{37}$ As can be seen on film footage of Pettiford from the 1950s, he eventually switched to using the anchored posture exclusively.
} 
automatically assume that Blanton used the anchored posture exclusively for his solo work. This also means that we are unable to confirm to what degree and for what specific purpose Blanton used the anchored and unanchored posture, but that he used both is clear. Although he might indeed be one of the first to start using the anchored posture, he certainly did not use it exclusively. ${ }^{38}$ Moreover, the MacKay footage suggests he played predominantly with the traditional posture, which might come as a surprise to some writers who came to think of Blanton as the first modern bassist.

As this first case study demonstrates, visual sources make it possible to nuance certain statements in regard to Blanton's technique and posture, and in the process serve as one of the tools that help to demystify him as a jazz bass icon. By revealing and contextualizing his right hand posture, it becomes clear that Blanton is not in every aspect the revolutionary modernist some claim or want him to be. It is of course not sufficient to base such a thesis solely on a visual analysis of this posture, but by combining this largely unexplored research tool with more commonly used methods such as music analysis, it is possible to gain a better insight into the actual impact of Blanton's bass playing. ${ }^{39}$ If, in turn, these insights are combined with those derived through other methods, including archival research, comparative case studies of other bassists, and musical experimentation, Blanton's bass playing, his style, and the techniques he used can be studied in a more holistic way.

So music iconography can be a concrete tool when researching playing techniques, body postures, and performance stances. To further illustrate this, let us examine Benjamin Givan's take of guitarist Django Reinhardt's left hand technique. Although the context is somewhat different, the basic premise is the same as in the above case study: visual evidence serves to support, contradict, or nuance previous statements made on the musician in question. In his study on Reinhardt (2010), Givan uses visual sources to gain insights into how the guitarist's left hand injury, which he sustained during a caravan fire at the age of eighteen, influenced his style and technique. It is commonly believed that the third and fourth finger of Reinhardt's left hand were paralyzed, severely

\footnotetext{
${ }^{38}$ Other visual sources show some of Blanton's contemporaries using the anchored posture as well, for example Red Callender in Gjon Mili's Jammin' The Blues (1944) and Milt Hinton (photographs during his tenure with Cab Calloway). It was not until the mid-1950s, however, that this posture became codified as the standard right hand posture for jazz bass playing.

${ }^{39}$ Of course music analysis encompasses a wide variety of methods. Depending on the music(ian) under study and the goal of the research, it can include anything from thematicmotivic analysis to semiotic analysis. There are several essays written on analysis in jazz; see for example "Analysing Jazz" by Thomas Owens for a brief overview of some analytical methods (in Cooke and Horn 2002).
} 
limiting his technical facility, but Givan presents a more nuanced conclusion. He states that although there can be no doubt that the guitarist's injury seriously limited his technique, Reinhardt was able to use his crippled fingers to some extent, and found other ways to overcome his disability, according to Givan even rendering the handicap "spectacularly irrelevant" (2010, 24). Of course he does not reach this conclusion based solely on visual analysis, as he supports his thesis with medical literature review and music analysis, but he does acknowledge that "[w]ithout visual evidence, recordings cannot always reveal conclusively how Reinhardt fingered a given chord" (2010, 18), thus underscoring the validity of music iconography in this particular case. Another parallel between the above example and this article's first case study can be drawn, since by contextualizing Reinhardt's left hand, Givan took away some of the "mystique [that] has surrounded not only Reinhardt's musical legacy but also his singular personal history" $(2010,7)$. Thus in both cases we get to see part of the musician himself, rather than the romanticized icon preferred by many writers. ${ }^{40}$

\section{THE UNANSWERED QUESTION ${ }^{41}$}

In the first case study as well as the aforementioned Reinhardt example, the visual nature of the main focus, Blanton's right hand and Reinhardt's left hand, combined with the clear layout of the double bass and guitar make it relatively easy to draw conclusions based on iconography. However, not every instrument or topic is as visually centered as the above. For example, can sound-related elements like tone and timbre also benefit from iconographic analysis? In this second case study I continue my pictorial analysis of Blanton, but focus on a non-visual aspect, arguing that even here visual sources might provide a useful perspective for further exploration.

Photographs can reveal much more than simply the accurate posture of one's hand. By re-examining some of the photographs included earlier in this article, other aspects are revealed that are not evident through hearing,

\footnotetext{
${ }^{40}$ Givan conducts a similar exercise in his article "Thelonious Monk's Pianism” (2009). Here he sheds new light on Monk's instrumental technique and uses filmed performances of Monk (clearly showing his hands while playing) to analyze his "pianism" properly. This provides Givan with better insights into "Monk's piano technique because [the concert films] reveal his physical posture, motion, and fingerings at the keyboard" (2009, 429). Incidentally, he also uses this visual evidence to nuance a statement made by Schuller to the effect that, in trying to avoid speculative statements, writers and scholars could benefit greatly from using pictorial sources.

${ }^{41}$ With apologies to Charles Ives for borrowing the title of his composition.
} 
transcribing or analyzing the music. As mentioned before, Blanton was often lauded for his pizzicato tone, even leading one critic to express her amazement at its volume: "Blanton's bass peels the ceiling six blocks away" (Cockrell 1941, 2-B). ${ }^{42}$ Although by contextualizing the bassist's right hand posture we get some insights on how he produced this tone, many questions posed earlier in this article remain unanswered. For instance, what exactly made Blanton's tone so voluminous? Or to put it differently: how was he able to "cut through" the sound of a full big band in an era when bass amplification as we know it today was non-existent?

As suggested before, an obvious answer lay in Blanton's own instrument, which may have had superior sound qualities. Photos show that he used the same double bass (from the brand line of the Czech Jan Juzek) throughout his tenure with Ellington, but not much more can be learned from pictures alone. Someone who might be able to provide more insights, is Richard Davis (born 1930), as he experienced this bass firsthand. He had Blanton's instrument on loan from Wendell Marshall for about ten years, and he recalled it was "very good and very loud" (telephone conversation with the author, October 11, 2014). But in the forty years between Blanton (1941) and Davis (ca. 1982) playing the double bass, its sound qualities might have been altered drastically, not only by using different types of strings (an active bassist will need to replace the strings at least once a year), but possibly also by more structural work, such as a refitting of the bridge or sound post. There are also many other variables that influence a bass's live sound projection that further cloud the issue: the acoustics and size of the venue, the number of attendees, and last but not least the nature of the engagement. (I discuss the specific context of the recording studio below.) For example, big bands often played for dances in ballrooms, whereas other engagements like shows in theatres or floor shows in night clubs had a seated audience, which influenced the "noise" coming from the audience and thus the projection of the band. ${ }^{43}$ All this makes it difficult to take the instrument's sound properties into account, although it is fair to say that Blanton's double bass was most certainly a factor. There are, however, other aspects that might help to answer the aforementioned question.

Nowadays double bass amplification in a live context relies on an intricate setup, with a transducer (a piezoelectric pickup, a bass microphone, or a combination of both), an amplification cabinet, and often the house public address system, all interconnected to get a full-fledged sound which can be

\footnotetext{
${ }^{42}$ As demonstrated in footnote 6, Blanton's arco tone was less appreciated.

${ }^{43}$ See "The Emergence of the Jazz Concert, 1935-1945" (DeVeaux 1989) for more on differences in concert venues and its impact on an audience.
} 
amplified to fill the need of the musicians and the performance venue. As one can imagine, this extensive way of amplifying the double bass was not used in the 1930s and 1940s, live or in the recording studio. Although the first double bass pickups were introduced in the early 1940s, it was only at the end of the 1960s, with the advent of steel strings and a dedicated double bass amplification cabinet, that double bassists in jazz started to use this technology to its fullest advantage. ${ }^{44}$ Prior to this, bassists played unamplified (the few exceptions mentioned in the previous footnote notwithstanding), and depended mainly on their sheer strength to be heard above the volume of the bands they performed with. Bassist Bill Crow (born 1927), who started his career in the 1950s, recalled how unamplified bassists relied on their own forceful playing, as well as on the sensitivity of fellow musicians:

You have to dig in hard to make the bass resonate well, but also sensitive musicians tend to hold their volume down in order to hear the bass notes. I was lucky to work with a number of drummers who controlled their volume level, making it possible for me to hear what I was playing. But I did play with some loud bands while playing unamplified, and I just had to trust that my sound was getting through (e-mail message to author, March 3, 2013).

This comment might hold a clue for understanding how Blanton was able to be heard so distinctly in the Duke Ellington Orchestra. The drummer in Ellington's so-called "Blanton-Webster band" was Sonny Greer, who was known for his subtlety. His playing focused more on the colors and dynamics of the drum set than on its metronomic function, and as a result was more "transparent" than that of some of his fellow-drummers. ${ }^{45}$ Because Greer had played in the band since 1924, the bassists prior to Blanton-among them Wellman Braud, Hayes Alvis and Billy Taylor-should have been equally favored by Greer's sensitive drumming. Indeed, critics as well as musicians, made note of their tone, especially Braud's forceful playing ("Basie-ite" bassist Walter Page marveled at how Braud "hit those tones like hammers and made them jump right out of that box" Driggs \& Page 1958, 12). Still, there must

\footnotetext{
${ }^{44}$ For more on bass gear, see for instance the online article "Jazz Bass: Essential Innovations: The Most Important Breakthroughs in Bass Gear History" by Ed Friedland (2012). Omitted in this article are some earlier experiments to "electrify" the double bass. A few "stick-like electric bass[es]," precursors of the current electric upright bass (or EUB), were being pioneered as early as 1940 by leading bassists such as Moses Allen, Vernon Alley and Howard Rumsey (Barnett 2006). Also see "The History of the Electric Bass part 1: Early Days" (Newell 2011).

${ }^{45}$ See for instance Annie Kuebler's appraisal of Greer's drumming (2012).
} 
have been something else besides Greer's drumming that distinguished Blanton's tone from that of his predecessors and caught the attention of many writers, both contemporary and more recent, as cited earlier. In photographs (1), (2), and (4) in this article, as well as photograph (5) below, we see that Blanton is positioned in the front line of the band, more or less adjacent to the reed instruments and in the crook of the piano. ${ }^{46}$ This position has two major advantages. First, it places the bass in front of all the other instruments in the band, allowing its sound to project directly into the audience. Second, the bass is relatively close to the soloist's/vocalist's microphone, in these days often the only kind of amplification available for the entire band. Furthermore, another photograph (not included in this article) clearly shows Blanton alone and up close to the microphone, suggesting that if he had a solo spot in an arrangement, he would simply step up to this microphone. ${ }^{47}$ Although the microphone would not have been at the optimal height (which for double bass is typically near the bridge and f-holes) nor would it be the best type for bass amplification, this setup would still allow the public to hear the bass solos much more clearly than had the bass been totally unamplified and at the back of the band. Of course this is still a far cry from a truly dedicated bass amplification, but it is the first important step towards a proper (double) bass amplification in a live context.

\footnotetext{
${ }^{46}$ In fact, all photos of Blanton with the Ellington band (another sixteen besides the five included in this article) show him in this (or a similar) position to the Ellington band.

${ }^{47}$ This photo can be seen via: http://brewlitesjazztales.files.wordpress.com/2011/06/jimmy_blanton_1.jpg (Leicht 2011, from the Fred Reif Collection). That this snapshot was not a mere coincidence, is suggested by a photo from February 1942 showing Alvin "Junior" Raglin, Blanton's replacement in the Ellington band, in almost the exact same position. For the latter photo, see https://jazzlives.files.wordpress.com/2014/09/duke-1941.jpg (Steinman 2014).
} 


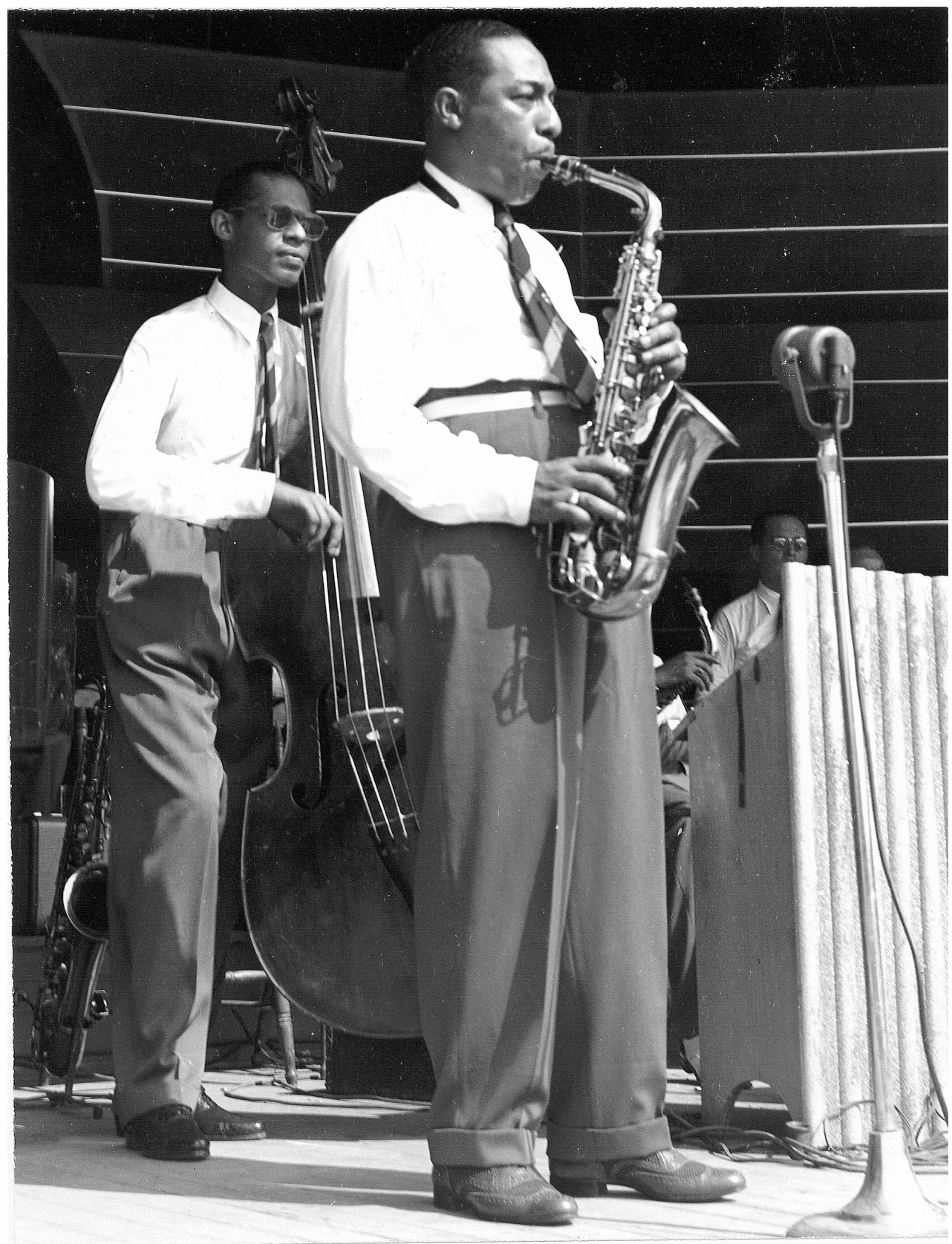

Photo 5: Blanton and Hodges, Eastwood Gardens, Detroit (MI), July 28, 1940 (Photographer unknown. Courtesy of the Fred Reif Collection).

By comparing the aforementioned photographs of Blanton with those of other bassists active in big bands during the 1930s and 1940s, it seems that 
positioning the bass-in the front line and near the microphone-was consistently used for the first time in the Ellington band upon the arrival of Blanton. One does find the occasional photo of a bassist in a similar front line position, but these are exceptions, and are possibly snapshots of the bass player briefly being featured. Indeed, bassists in Ellington's pre-Blanton band as well as in other Swing Era big bands were usually positioned more toward the back of the band, often near the drum set, guitar, and piano. ${ }^{48}$ Although this is a logical location, since the close proximity of the four rhythm section members helps them to firmly lock their groove, it does obscure the bass's sound somewhat as it blends much more with the sound of the other instruments in the band, and is thus less distinctly audible by the public. It is my belief that the front line positioning was a conscious effort of Ellington to make Blanton's bass playing a truly central aspect of his band sound. Although Ellington always had an affinity for the bass-Blanton was far from the first Ellingtonian to play bass solos-his young bassist quickly became one of the band's star soloists, and a central stage position not only seemed logical but even vital. ${ }^{49}$ Moreover, the Ellington - Strayhorn team wrote pieces that featured the bass to a much greater extent and with more variety than most other contemporary composers. For example by having the bass double melodic parts (e.g., the ritornello in "Jack the Bear") or play singular counterpoint lines (e.g., "Concerto for Cootie"), they truly integrated the double bass as a lead voice in the orchestra, not merely showcasing it as a novelty instrument.

Blanton apparently worked as a catalyst, sparking Ellington to experiment more extensively with the double bass, both from a compositional as well as a more practical point of view by deliberately giving the instrument a front line position. In fact, if the stage of the venue allowed it, Ellington would continue to give his bassists this prime spot, as evidenced by many photos of the postBlanton bands. (It must be noted that at least since 1958 Ellington's bassists were sometimes given their own microphones, and as a consequence there was not always a need to put them in the front line anymore.)

As illustrated, analyzing photographs aid in better understanding how Blanton was able to be heard so distinctly that his tone consistently caught the attention

\footnotetext{
${ }^{48}$ Ellington's piano (as was Count Basie's) was atypically more up front as he was leading the band from behind it.

${ }^{49}$ Besides reviews that show that Blanton-associated tunes (like "Jack the Bear" and "Sepia Panorama") were part of the band's regular repertoire, there are contemporary reports that illustrate the bassist's stature as a featured soloist. One critic even wrote that during a concert in Washington, D.C., "Jimmy Blanton, on bass, stole the show. Everybody marveled at his abilities” (Baker 1940, 19).
} 
of writers. However, the photographs under discussion were all taken during live concerts and dances, rather than in the recording studio. Hence we are missing an important part of the music's reception since many critics base(d) their judgments of a band and its musicians on the recordings they made. ${ }^{50}$ This is also the case with Blanton, whose earliest critical evaluations, for instance in Down Beat, Metronome and Jazz Information, appear primarily in record reviews. Several newspapers did review live or broadcasts of Ellington performances, and Blanton is mentioned a couple of times (see for instance the penultimate footnote, or Cockrell 1941, 2-B), but our exploration of his tone would be incomplete if we do not take the properties of the recording studio into consideration as well.

Regrettably, only one photograph of the 1939-1941 Ellington band in the studio has surfaced so far, possibly from their first Victor recording session on March 6, 1940. ${ }^{51}$ Although Blanton's double bass is seen lying on the studio floor, the man himself is nowhere to be seen, but the photo does suggest that Blanton is positioned differently here than he is live. His music stand (which can be identified from his bow lying on top of it and his bass in front of it) sits neatly between Greer's drum kit and the trombone section. There also appears to be no dedicated microphone for Blanton (in fact, no microphones at all are visible). This is a sharp deviation from the standard practice during their live engagements, which found Blanton slightly in front of the band and close to a microphone. Was this the regular setup of the Ellington band in the recording studio at this time? Or is this merely a snapshot of a pre-recording rehearsal that does not accurately depict the band in the process of "waxing"? Moreover, the whole band is not visible, nor do we see much of the room's acoustic features. With so many unknowns and just this one photo at hand, there is not much conclusive evidence, and Blanton's exact setup and position in the studio remain unknown.

However, earlier pictures of the Ellington band in the studio might provide some clues. Two photos, one from 1936 in the ARC Studios and one from 1938 during a CBS Saturday Night Swing Club broadcast, clearly show Blanton's predecessor Billy Taylor positioned in front of the band and near the microphone, a setup that at that time was not yet used in live situations, as

\footnotetext{
${ }^{50}$ For more writings on the role recordings played in the formation of the jazz canon, see Jed Rasula's "The Media of Memory: The Seductive Menace of Records in Jazz History" in Jazz Among the Discourses (ed. Gabbard 1995) or the chapters "Jazz and the Disembodied Voice" and "Men Can't Help Acting on Impulse!" in Whyton 2010.

${ }^{51}$ See https://jazzlives.files.wordpress.com/2013/01/dukes-brass-c-1940.jpg to view this photo (Steinman 2013).
} 
visual sources clearly illustrate. ${ }^{52}$ The 1936 photo even shows Taylor with a dedicated microphone in front of him. Also, a promotional film from 1937 shows the Duke Ellington Orchestra in the recording studio with Taylor up close to the main microphone. ${ }^{53}$ So it seems Ellington made sure the bass was well recorded even prior to Blanton's hiring. Although speculative, it would only seem logical that Blanton was also recorded with a similar setup as Taylor, but why Taylor's tone never garnered as much attention as Blanton's did remains an unanswered question, although Victor's superior recording technique might be a factor. ${ }^{54}$

Unfortunately, apart from these clues, visual sources cannot conclusively reveal anything more. Nonetheless, this case study still gives us valuable insights into the more technical aspects of Blanton's bass playing and Ellington's emphasis on giving the bass a central role in his band's sound. On a general level, it also helps to further demystify Blanton, showing that his much lauded tone does not simply springs out of nowhere-or as some would argue, from his "genius" alone-, but is at least partially grounded in a very practical and straightforward solution: moving the bass closer to the microphone.

\section{ICONOGRAPHY: FROM THEORY TO PRACTICE}

In both the above case studies, music iconography was used as a theoretical research tool, but as one can imagine it also has practical purposes, and as such is relevant for the performance aspects in jazz. Using iconography as such is not new in music. The past century has seen the gradual rise of an interest in historical performance of Western classical music, and music specialists in cooperation with performers-though often one and the same person-have been using visual representations as one of the possible tools for reconstructing music from the Baroque, Renaissance and Medieval eras, and often even earlier

\footnotetext{
${ }^{52}$ The ARC photo can be seen via:

http://www.pointofdeparture.org/PoD33/img/pod33_po.jpg (Shoemaker 2011, from the Steven Lasker Collection). The CBS photo is part of the Frank Driggs Collection (Archives Center, National Museum of American History, Smithsonian Institution).

${ }^{53}$ The clip, Record Making with Ellington, can be found on: http://www.youtube.com/watch?v=SJ0Vn7ul42s.

${ }^{54}$ The Blanton-Webster band recorded predominantly for Victor, its first release dated March 6, 1940. Critics were quick to notice the difference with the previous Brunswick records: "Not only is the music superb, but the recording, technically, is perfect. Balance and surface reach a new peak with this release [i.e., "Morning Glory" and "Jack the Bear", Ellington's first Victor sides]" (Barrelhouse Dan 1940a, 15).
} 
times. ${ }^{55}$ In the majority of the cases the goal was to actually perform the music in its "correct" historical context, a practice that over time became known as historically informed performance, or by its acronym HIP or HIPP (adding an extra "P" for practice). ${ }^{56}$ More recently, HIP was also used in more "modern" styles of classical music, such as Romantic music, or even $20^{\text {th }}$ century "jazzy" compositions such as George Gershwin's "Rhapsody in Blue" (1924)..$^{57}$

However, the concept of HIP, and especially the use of iconography to inform this practice, is virtually non-existent in jazz. Worldwide there are a host of repertory groups or tribute bands dedicated to historical jazz repertoire, but the number of ensembles that attempt to recreate or approximate a historically informed performance is small: there is the odd experiment, such as The 1930s Recording Project, an album recorded using a single RCA ribbon microphone from 1938 (but not 100\% HIP in that the bassist did not use gut strings), and when in New York City, one can get a musical taste of the Roaring Twenties, courtesy of Vince Giordano and the Nighthawks. But the band most often associated with authenticity is the Jazz at Lincoln Center Orchestra (or JLCO). This big band does not use direct bass amplification in the studio or on stage-indeed, the tag line "to obtain more wood sound from the bass, this album was recorded without usage of the dreaded [italics in original] bass direct" was coined by Delfeayo Marsalis, the brother of JLCO director Wynton-but even they do not strive for a 100\% accurate HIP. The bassist, for example, does not use the unanchored right hand posture in arrangements of pre-1940s jazz (but he does use gut strings). The choice for not fully adopting HIP is often driven by economic, technical, and practical needs as well as other limitations, and I do not mean to suggest that bands playing a historical repertoire should all necessarily adopt HIP. Moreover, its use might have implications for the music and the performer's attitude: "[R]eenacting recorded jazz performances in their exactitude [...] can be read as moving beyond the bounds of simple imitation, homage and historical research

\footnotetext{
${ }^{55}$ See for instance The Historical Performance of Music: An Introduction by Colin Lawson and Robin Stowell (1999) for a historical overview.

${ }^{56} \mathrm{As}$ one can imagine, HIP is a highly debated topic among music scholars, touching upon subjects such as authenticity, canonization and (post)modernism. John Butt's Playing with History: The Historical Approach to Musical Performance (2002) provides a good overview of some of these debates.

${ }^{57}$ This reconstruction can be found on The Birth of Rhapsody in Blue: Paul Whiteman's Historic Aeolian Hall Concert of 1924, conducted by Maurice Peress (recorded in 1987, reissued on CD in 1996). Peress later also recorded America's "bad boy of music" George Antheil's Ballet Mécanique: A Recreation of His Carnegie Hall Concert of 1927 (recorded in 1990, reissued in 2010), which includes his 1925 "A Jazz Symphony."
} 
towards a morbid fascination with iconic records of jazz history," observes Whyton (2010, 54). I would argue, however, that HIP should be used primarily as a practical research tool, with music iconography supporting it, and not as a means to appropriate the past and present it as the only correctand thus legitimate-version of a performance. It can be enriching for those musicians and bands wishing to experiment with older styles and techniques in jazz, however, especially in the context of historical or musicological research, and in doing so they can-indeed, even should-use music iconography as one of the sources on which to base their explorations.

\section{A FRESH PAIR OF EYES}

Naturally, music iconography has its disadvantages and limitations. Although the history of jazz is relatively short, especially in comparison with other musical genres that use iconography to inform their performances, visual sources are often surprisingly scant. It is hard to believe that so few images, still or moving, exist of certain musicians and bands that are widely considered essential to the jazz canon, such as alto saxophonist Charlie Parker (though a fair amount of photographs exist, his appearance in film clips runs under ten minutes) or Duke Ellington (of whom photo material of key events like his Carnegie Hall concerts of the 1940 s is not widely available).$^{58}$ Naturally this scarcity or inaccessibility of sources can reduce the effectiveness of an iconographical analysis.

Moreover, not every photo, film or other type of image (for instance graphics in advertisements) is usable in every context. As I wrote earlier, posed photographs can be problematic since they do not always accurately depict performance postures, setup of instruments, and the placement of a band, among other factors. ${ }^{59}$ One must also be aware of a photo's instantaneous nature, capturing the performer(s) in a fraction of a second, which might not always be an accurate portrayal of musician's or band's most typical posture, stance, or position. The same problem arises with films, which are often

\footnotetext{
${ }^{58}$ See for instance Meeker (2014) for a general filmography, or Klaus Stratemann's Duke Ellington: Day by Day and Film by Film (1992) for a filmography focusing on Ellington. In the case of Ellington's Carnegie Hall concerts, photos of these performances and their rehearsals are to be found in the contemporary program brochures, which are now collector's items.

${ }^{59} \mathrm{An}$ example is the debate that surrounds the single surviving photograph of cornetist Charles "Buddy" Bolden. In this posed photo there seem to be a number of unorthodox postures which continue to puzzle scholars to this day. More about this photographical conundrum can be found in "History, Myth and Legend" by David Sager (in Cooke and Horn 2002) and volume XXII of The Jazz Archivist (2009).
} 
dubbed and place the band or musician in the artificial setting of a film studio, not to mention the fact that musicians had to follow the instructions of a director who naturally looked for visual flair or drama rather than authenticity. In the above cases it is up to the researcher to question the usability of the image, and if used as a study object, to contextualize it properly. Finally, iconographical analysis is not a substitute for well-tested research methods, but it can in certain cases provide a valuable, indeed sometimes even essential addition, especially if complemented and cross-referenced with other sources, both written and auditory.

As demonstrated in the two above case studies, music iconography is a valuable research tool on multiple levels. Firstly, it can reveal relevant information about the performance practice, such as the stances, positions and instruments that were used, as well as give an insight into the performance context, for instance the social and racial composition of the audience, the type of venue a band played in, etc. Secondly, on a more general level it is one of the many means that might help to at least partially demythologize jazz icons by looking beyond the romanticized image people have of these musicians. It might even proffer suggestions that help to explain aspects not as easily analyzed, such as tone, and are thus prone to mystification. Furthermore, besides these more theoretical applications, jazz iconography can also serve more practical purposes, specifically to inform HIP, a field of jazz research/performance yet to be fully explored. Hence, visual sources in jazz serve a multitude of purposes, ranging from the purely esthetical to music experimentation and performance. We should continue to look at photographs and films for their iconic as well as artistic value, but looking at them with a fresh pair of eyes might be equally as rewarding.

\section{REFERENCES}

"Artie Bernstein Back to Coast Studios Forsaking the Hot and Harrowed." 1941. Metronome 57, no. 7 (July): 11.

Baker, Whitey. 1940. “Accuse Duke of 'Big Shot' Attitude.” Down Beat 7, no. 13 (1 July): 19.

Barnett, Anthony. 2006. "Electric Violins and Jazz Violinists 1930s-1950s - PART 2." Fiddle Sessions ${ }^{\circledR}, \quad$ April. Accessed December 18, 2013. http://archive.fiddlesessions.com/apr06/electric.html.

Barrelhouse Dan. 1940a. "Record Reviews.” Down Beat 7, no. 8 (15 April): 15. 1940b. “Record Reviews.” Down Beat 7, no. 18 (15 September): 14. 
“Ben Webster Joins Ellington.” 1940. Jazz Information 1, no. 19 (26 January): 6.

Bozarth, Rex O. 1981. "An Assessment of the Role of James 'Jimmy' Blanton in the Development of Jazz Bass." Problem in lieu of thesis, North Texas State University.

Bradford Robinson, J. 1986. "Blanton, Jimmy [James]." The New Grove Dictionary of American Music and Musicians, 2:232. London: Macmillan. 1988. "Blanton, Jimmy [James]." The New Grove Dictionary of Jazz, 1:117. London: Macmillan.

. 2001. "Blanton, Jimmy [James]." Grove Music Online. Accessed November 2, 2011. http://www.grovemusic.com . 2002. "Blanton, Jimmy [James]." The New Grove Dictionary of Jazz, $2^{\text {nd }}$ ed., 1:238. London: Macmillan.

"Brother and Sister Gave Benny Bernstein" 1939. Metronome 55, no. 7 (July): 11.

Brown, Ray. 1980. "Blanton, Jimmy [James]." The New Grove Dictionary of Music and Musicians, 2:784. London: Macmillan.

Butt, John. 2002. Playing with History: The Historical Approach to Musical Performance. Cambridge: Cambridge University Press.

Campbell, Jeffrey. 2002. "Two Profiles in the Development of Jazz Bass Playing: A Study of Jimmie Blanton and Ron Carter." PhD diss., The University of Rochester.

Campbell, Murray. 2001. "Timbre." The New Grove Dictionary of Music and Musicians, $2^{\text {nd }}$ ed., 25:478. London: Macmillan.

Chevan, David. 1989. “The Double Bass as a Solo Instrument in Early Jazz.” The Black Perspective in Music 17, nos. 1-2: 73-92.

Clark, Dave. 1940. “Jim Blanton’s Mom Has Fine Jump Combo.” Down Beat 7, no. 3 (15 December): 19.

Cockrell, Wilma. 1941. "Jam Session.” The California Eagle (29 May): 2-B.

Crane, Frederick. 1986. "Black American Music in Pictures: Some Themes and Opportunities.” Black Music Research Journal 6: 27-47. Accessed June 28, 2013. http://www.jstor.org/stable/779252

DeVeaux, Scott. 1989. “The Emergence of the Jazz Concert, 1935-1945.” American Music 7/1: 6-29. Accessed August 8, 2012. http://www.jstor.org/stable/3052047 . 1991. "Constructing the Jazz Tradition: Jazz Historiography." Black American Literature Forum 25, 3: 525-60. Accessed June 28, 2013. http://www.jstor.org/stable/3041812 
, and Gary Giddins. 2009. Jazz. New York: W.W. Norton \& Company.

Dexter, Dave Jr. 1941a. “Records Reviews.” Down Beat 8, no. 11 (1 June): 15. . 1941b. "Started It All..." Down Beat 8, no. 15 (1 August): 4.

dix. 1942. "Former Pals Mourn Loss Of Blanton." Down Beat 9, no. 16 (15 August): 6.

Drabkin, William. 2001. "Tone." The New Grove Dictionary of Music and Musicians, $2^{\text {nd }}$ ed., 25:599. London: Macmillan.

Driggs, Frank and Walter Page. 1958. “About My Life In Music.” The Jazz Review 1, no. 1 (November): $12-15$.

“Duke's Blanton Dead at 24." 1942. Metronome 58, no. 9 (September): 11.

“Duke's New Bass...” 1939. Down Beat 6, no. 15 (15 December): 13.

Ellington, Edward Kennedy (Duke). 1973. Music is My Mistress. New York: Da Capo Press.

Emge, Charlie. 1942. "Jimmy Blanton Takes Last Ride: Goes Home on Chattanooga Choo-Choo." Down Beat 9, no. 16 (15 August): 12.

Feather, Leonard G. 1942. "Who's Who in Music: Benny Goodman's Band.” Down Beat 9 , no. 2 (15 January): 6. 1959. The Book of Jazz. New York: Meridian Books, Inc.

Freedman, Richard V. 1940. "Is Al Morgan the 'Forgotten Man' of American Jazz?" Down Beat 7, no. 3 (1 February): 6.

Freeman, Ken. 1941. "Music and Musicians." The California Voice. (28 November): 5.

Friedland, Ed. 2012. "Jazz Bass: Essential Innovations: The Most Important Breakthroughs in Bass Gear History.” JazzTimes, September 4. Accessed August 12, 2013. http://jazztimes.com/articles/29840-jazz-bass-essential-innovations

Gabbard, Krin. 1995. "Introduction: The Jazz Canon and Its Consequences." In Jazz Among the Discourses, edited by Krin Gabbard, 1-28. Durham: Duke University Press.

. 2002. "Images of Jazz." In The Cambridge Companion to Jazz, edited by Mervyn Cooke and David Horn, 332-46. Cambridge: Cambridge University Press.

Garrison, Bob. 1945. “First Bassman- Jimmy Blanton.” Band Leaders (March): 60.

Gioia, Ted. 1997. The History of Jazz. New York: Oxford University Press.

Givan, Benjamin. 2009. “Thelonious Monk's Pianism.” The Journal of Musicology 26/3: 404-42. Accessed June 28, 2013. http://www.jstor.org/stable/10.1525/jm.2009.26.3.404 
. 2010. The Music of Django Reinhardt. Ann Arbor: The University of Michigan Press.

Goldsby, John. 2002. The Jazz Bass Book: Technique and Tradition. San Francisco: Backbeat Books.

Gottlieb, Edward. 1941. "Chords and Discords: If Mr. Dexter Would Take a Few Lessons On String Bass...” Down Beat 8, no. 12 (15 June): 10-11.

Hasse, John Edward. 1993. Beyond Category: The Life and Genius of Duke Ellington. New York: Da Capo Press.

Hentoff, Nat. 1955. "Marshall, Bass On Own After 6 Years With Duke.” Down Beat 3, no. 6 (23 March): 6.

Hinton, Milton. 1941. "Milton Hinton's Advice to Bassists." Music and Rhythm 2, no. 9 (August): 38.

Kernfeld, Barry. 1995. What to Listen for in Jazz. New Haven: Yale University Press.

Kirby, John. 1942. "My 10 Favorite Bass Players." Music and Rhythm 2, no. 17 (May): 10.

Kolodin, Irving. 1941a. "The New Records.” The New York Sun (22 March): 22. . 1941b. "The New Records." The New York Sun (17 May): 29.

Koonce, David. 1946. “Late Jimmy Blanton Bassdom’s Greatest.” Metronome 62, no. 8 (August): 48-49.

Kuebler, Annie. 2012. "The Duke at Fargo: Liner Notes from The Duke at Fargo 1940: Special $60^{\text {th }}$ Anniversary Edition (Storyville STCD 8317/17)." Journal of Jazz Studies 8/2: 137-62. Accessed February 7, 2014. http://jjs.libraries.rutgers.edu/index.php/jjs/article/view/43/42

Law, William. 1994. "Establishing Jimmy Blanton as The Father of Modern Jazz Bass Through Examination of Selected Works.” Master's thesis, Moorhead State University.

Lawson, Colin, and Robin Stowell. 1999. The Historical Performance of Music: An Introduction. Cambridge: Cambridge University Press.

Lipsitz, George. 2004. "Song of the Unsung: The Darby Hicks History of Jazz." In Uptown Conversation: The New Jazz Studies, edited by Robert G. O’Meally, Brent Hayes Edwards, and Farah Jasmine Griffin, 9-26. New York: Colombia University Press.

Martin, Henry, and Keith Waters. 2014. Essential Jazz: The First 100 Years, $3^{\text {rd }}$ Edition. Boston: Schirmer Cengage Learning.

McRae, Barry. 1967. “A B Basics: No. 2. Jimmy Blanton.” Jazz Journal 20, no. 2 (February): 15. 
Meeker, David. 2014. Jazz on the Screen: A Jazz and Blues Filmography. Washington, DC: Library of Congress. Accessed October 12, 2014. http://lcweb2.loc.gov/natlib/ihas/warehouse/jots/200028017/0001.pdf

“Metronome's Hall of Fame: Artie Shapiro.” 1941. Metronome 57, no. 7 (July): 24.

Newell, Roger. 2011. "The History of The Electric Bass part 1: Early Days.” Accessed December 18, 2013. http://www.musicradar.com/news/bass/the-history-of-theelectric-bass-part-1-early-days-507234

"Norman Granz Presents The Duke Ellington Concert, Gerry Mulligan, Dave Brubeck, Stan Getz." 1954. Program brochure to Norman Granz's “Modern Jazz Concert" tour, 15 October to 8 November.

Owens, Thomas. 2002. “Analysing Jazz.” In The Cambridge Companion to Jazz, edited by Mervyn Cooke and David Horn, 286-97. Cambridge: Cambridge University Press.

Palmer, Robert. 1974. Liner notes to The Bass. ABC Impulse ASY-9284/3. Long player.

Porter, Lewis. 1991. "Book Review: The Swing Era.” In Annual Review of Jazz Studies 5, edited by Edward Berger, David Cayer, Dan Morgenstern and Lewis Porter, 183-200. Lanham: Scarecrow Press.

. 1998. John Coltrane: His Life and Music. Ann Arbor: The University of Michigan Press.

Priestley, Brian. 1982. Mingus: A Critical Biography. New York: Da Capo Press. . 2011. "Charlie Parker and Popular Music." In Jazz, edited by Tony Whyton, 203-19. Farnham: Ashgate.

Rasula, Jed. 1995. "The Media of Memory: The Seductive Menace of Records in Jazz History." In Jazz Among the Discourses, edited by Krin Gabbard, 134-62. Durham: Duke University Press.

Research Center for Music Iconography. 2013. “About.” Accessed August 12, 2013. http://rcmi.gc.cuny.edu

Sager, David. 2002. "History, Myth and Legend: The Problem of Early Jazz." In The Cambridge Companion to Jazz, edited by Mervyn Cooke and David Horn, 270-85. Cambridge: Cambridge University Press.

Schuller, Gunther. 1989. The Swing Era: The Development of Jazz, 1930-1945. New York: Oxford University Press.

Shapiro, Artie. 1941. "Artie Shapiro's Advice to Bassists." Music and Rhythm 2, no. 11 (October): 33. 
Simmons, John. 1941. "Who Is the Best Man On Your Instrument?" Music and Rhythm 1, no. 6 (April): 32-33.

Simon, George. 1942a. "McIntyre, MacShann Lead Fine Bands." Metronome 58, no. 3 (March): 22. . 1942b. "Powell, Hampton Bands Rate Raves." Metronome 58, no. 5 (May): 14.

“'Slim' Taft, Dorsey Bros. Bassist, Dies on Coast.” 1941. Down Beat 8, no. 8 (15 April): 8.

Sords, Charles C. 1941. "Chords and Discords: 'To Hell with the Long-Haired Jerk!' Dex Stands Avenged.” Down Beat 8, no. 14 (15 July): 10.

Straka, Manfred. 2000. "Blanton, James, gen. Jimmy." Die Musik in Geschichte und Gegenwart: Allgemeine Enzyklopädie der Musik, 3:50-51. Kassel \& Stuttgart: Bärenreiter Metzler.

Stratemann, Klaus. 1992. Duke Ellington: Day by Day and Film by Film. Copenhagen: JazzMedia ApS.

Tanner, Lee. 2006. The Jazz Image: Masters of Jazz Photography. New York: Harry N. Abrams.

Toll, Ted. 1941. “Simmons, with B.G. Another Negro, Bassist.” Down Beat 8, no. 15 (1 August): 2.

Ulanov, Barry. 1942. "Band Reviews: Lucky Millinder." Metronome 58, no. 2 (February): 26.

. 1950. "The Four Man Who Made Modern Jazz." In Jazz 1950: The Metronome Yearbook, edited by George Simon and Barry Ulanov, 19-22. New York: Metronome Corporation. 1952. A History of Jazz in America. New York: The Viking Press.

van de Leur, Walter. 2002. Something to Live for: The Music of Billy Strayhorn. New York: Oxford University Press.

White, Hayden. 1973. Metabistory: The Historical Imagination in Nineteenth-Century Europe. Baltimore: The John Hopkins University Press.

Whyton, Tony. 2010. Jazz Icons: Heroes, Myths and the Jazz Tradition. Cambridge: Cambridge University Press.

William Ransom Hogan Jazz Archive, The. 2009. "That Buddy Bolden Band Photograph.” The Jazz Archivist, vol. XXII. Accessed August 11, 2013. http://jazz.tulane.edu/sites/all/themes/Howard_Tilton/docs/jazz_archivist/Jazz_A rchivist_vol22_2009.pdf

Wright, Gordon. 1940. “Record Reviews.” Metronome 56, no. 1 (January): 18. 
1941. "Record Reviews." Metronome 57, no. 3 (March): 32.

Ye Scribe. 1939a. "In The Groove." The Indianapolis Recorder (9 December): 12. 1939b. "In The Groove." The Indianapolis Recorder (23 December): 12.

\section{AUDIOVISUAL MATERIAL}

1930s Jazz Recording Project, The. 2011. The Jazz Recording Project. Played by Ian Bateman, John Hallam, Spats Langham, Martin Litton, Richard Pite, Malcolm Sked, Andy Woon. Lake Records LACD 321. Compact disc.

Antheil, George. 2010. George Antheil's Ballet Mécanique: A Recreation of His Carnegie Hall Concert of 1927. New Palais Royale Orchestra conducted by Maurice Peress. Nimbus Records NI 2567. Compact disc. [Also includes other performers.]

"Duke Ellington: Reminiscing in Tempo." 1991. The American Experience, season 4, ep. 8. Produced and directed by Robert Levi, written by Robert Levi and Geoffrey C. Ward. VHS.

Ellington, Edward Kennedy (Duke). 1999. “Concerto for Cootie.” The Duke Ellington Centennial Edition: Complete RCA Victor Recordings: 1927-1973, disc 8. Played by The Duke Ellington Orchestra, March 15, 1940. RCA/Victor 09026-63386-2. Compact disc.

, and Billy Strayhorn. 1999. "Jack The Bear." The Duke Ellington Centennial Edition: Complete RCA Victor Recordings: 1927-1973, disc 8. Played by The Duke Ellington Orchestra, March 6, 1940. RCA/Victor 09026-63386-2. Compact disc.

. 1999. “Sepia Panorama - Take 1.” The Duke Ellington Centennial Edition: Complete RCA Victor Recordings: 1927-1973, disc 9. Played by The Duke Ellington Orchestra, July 24, 1940. RCA/Victor 09026-63386-2. Compact disc.

Gershwin, George. 1996. The Birth of Rhapsody in Blue: Paul Whiteman's Historic Aeolian Hall Concert of 1924. Conducted by Maurice Peress. Music Masters MMD 20113X/14T. Compact disc. [Also includes work by other composers.]

Harry Carney Home Movies, Ruth Ellington Collection, Archives Center, National Museum of American History, Smithsonian Institution.

Hawkins riff tune - 1945. 2011. YouTube video, 2:04. Posted by "erwigfilms," January 21. Accessed August 12, 2013. http://www.youtube.com/watch?v=UQh-tqrhn28

JAZZ E SWING DANCE 1944 (Jammin' The Blues) (Better Picture Quality). 2014. YouTube video, 10:15. Posted by "Bill Green," August 31. Accessed November 7, 2014. http://www.youtube.com/watch?v=2Kh2qEzyZ1M. 
Jazz: A Film by Ken Burns. 2000. Produced and directed by Ken Burns and Lynn Novick, written by Geoffrey C. Ward. PBS DVD B8262D. 10 DVDs.

Leicht, Bruno. 2011. "Since we're still in JUNE, here's Barney Bigard..." Brew Lite's Jazz Tales. Accessed December 18, 2013. http://brewlitesjazztales.wordpress.com/2011/06/29/since-were-still-in-junetheres-barney-bigard/

Ray Brown - Double Bass Master class.avi. 2011. YouTube video, 36:15. Posted by “Charas Manali," November 11. Accessed August 12, 2013. http://www.youtube.com/watch?v=SmoIvdWJpdQ

Record Making with Ellington. 2012. YouTube video, 5:06. Posted by "bassling," April 21. Accessed August 12, 2013. http://www.youtube.com/watch?v=SJ0Vn7ul42s

Shoemaker, Bill. 2011. "Page One: A Column by Bill Shoemaker." Point of Departure: An Online Music Journal. Accessed August 11, 2013. http://www.pointofdeparture.org/PoD33/img/pod33_po.jpg

Steinman, Michael. 2013. Jazz Lives. Accessed November 7, 2014. https://jazzlives.files.wordpress.com/2013/01/dukes-brass-c-1940.jpg

2014. Jazz Lives. Accessed November 7, 2014. https://jazzlives.files.wordpress.com/2014/09/duke-1941.jpg

\section{ABOUT THE CONTRIBUTOR}

MATTHIAS HEYMAN is currently working on his $\mathrm{PhD}$ research at the University of Antwerp (Belgium) in affiliation with the AP University College (Royal Antwerp Conservatoire), where he obtained a Master's degree in Jazz Double Bass. In his research he seeks to contextualize the bass playing of Ellingtonian Jimmie Blanton (1918-1942). His other research interests include the history of jazz double bass as well as Belgian jazz history. Heyman is also active as a freelance double bass player and teaches all jazz history courses at the Jazz Studio (Antwerp) and the LUCA School of Arts (Leuven).

The Journal of Jazz Studies (JJS) is published by the Institute of Jazz Studies at the Newark campus of Rutgers, The State University of New Jersey. JJS is hosted online by the Rutgers University Libraries at http://jjs.libraries.rutgers.edu. 